\title{
Planning for Future Research in Public Universities in Uncertain Times
}

\author{
Merrill Series on \\ The Research Mission of Public Universities
}

A compilation of papers originally presented at a retreat sponsored by The Merrill Advanced Studies Center

July 2014

\author{
Mabel L. Rice, Editor \\ Technical editor: Evelyn Haaheim
}

MASC Report No. 118

The University of Kansas

(C) 2014 The University of Kansas Merrill Advanced

Studies Center or individual author 


\section{TABLE OF CONTENTS}

MASC Report No. 118

\section{Introduction}

Mabel L. Rice

.vi

Director, Merrill Advanced Studies Center, the University of Kansas

Executive summary viii

\section{Keynote address}

Sally Frost Mason

President, the University of Iowa

Planning for Future Research in Public Universities in Uncertain Times

\section{Panel 1: Research Administrators}

Harvey Perlman

Chancellor, University of Nebraska

Engaging with the Private Sector: Nebraska Innovation Campus

Brian Foster .25

Provost and Professor Emeritus, University of Missouri Adaptive Planning in a Chaotic Research Environment: Aligning Academic and Business Issues

Jeffrey Scott Vitter

Provost and Executive Vice Chancellor, University of Kansas

Julie S. Nagel

Executive Director of Corporate Partnerships, University of Kansas

Enhancing University Research through Corporate Engagement and Collaboration

\section{Panel 2: Researchers}

Baskar Ganapathysubramanian

Assistant Professor, Mechanical Engineering, Iowa State University Revolutionizing science through simulation: A junior researcher's perspective on research challenges in uncertain times

Jonathan Brumberg

Assistant Professor, Speech-Language-Hearing, University of Kansas

Interdisciplinary collaborations at work in brain-machine interfacing

Shannon Bartelt-Hunt

Associate Professor, Civil Engineering, University of Nebraska

Collaborative research between engineering and life sciences: Influences of surface

attachment on the biological properties of proteins 


\section{Panel 3: Research Administrators}

Danny Anderson ................................................................................................. 70

Dean, College of Liberal Arts \& Sciences, University of Kansas

Research, Productivity, and Pressures on Faculty in an Era of Disruptive Change

John F. Leslie 78

Head, Dept. of Plant Pathology, Kansas State University

Stabilizing Research Departments in a 10\% World

Mark McIntosh

Professor and Chair, Molecular Microbiology and Immunology, University of Missouri Strategic Investments in Research in Microbiology and Immunology - Importance of Technology Infrastructure

\section{Panel 4: Research Administrators}

Karen Burg.

Vice President for Research, Kansas State University

Planning Interdisciplinarity in Uncertain Times: Research Centers

Henry Foley

Senior Vice Chancellor for Research and Graduate Studies, University of Missouri

The New Role of Land Grant Universities in the 21 ${ }^{\text {st }}$ Century: An Essay

Prem Paul

Vice Chancellor for Research and Economic Development, University of Nebraska

Top Secrets to Growing University Research in Uncertain Times

Sarah Nusser

Vice President for Research, Iowa State University

Research Administration and Leadership - Perspectives of a New VPR

\section{Panel 5: Research Administrators}

Michele Kennett

Assistant Vice Chancellor for Research, University of Missouri

Anticipating New Directions in Human Subjects Research

Chitra Rajan

Associate Vice President for Research, Iowa State University

Developing Research Capacity and Infrastructure

Richard Barohn

Vice Chancellor for Research, University of Kansas Medical Center

Laura Herbelin, BSc - Research Instructor, Department of Neurology, University of Kansas Medical Center

Lauren S. Aaronson, PhD, RN, -Professor, School of Nursing and Dept. of Health Policy \& Management, School of Medicine; Deputy Director, Frontiers: The Heartland Institute for Clinical and Translational Research, University of Kansas Medical Center

Clinical Research: New Frontiers 
Joseph Heppert

Associate Vice Chancellor for Research, University of Kansas

Can research inform us about the efficacy of University STEM education?

\section{Panel 6: Administrators and Researchers}

Kurt Preston

Associate Vice Chancellor for Research, University of Nebraska

Department of Defense Research Funding: Opportunities, Idiosyncrasies, and Risk Analysis

Emily Smith 152

Associate Professor, Dept. of Chemistry, Iowa State University

The argument for investing in expensive research endeavors: Analytical Chemistry as an example

Joy Ward 158

Associate Professor, Ecology and Evolutionary Biology, University of Kansas

Enhancing the Success of Early Career Faculty in STEM Fields During Uncertain Times

Chris Sorensen. 166

Courtelyou-Rust University Distinguished Professor, Kansas State University 37 Years an Academic Scientist 